\title{
The Aesthetics of Violence in the Case of Gaius Martius Coriolanus
}

\author{
APOSTOLOS N. STAVELAS / Athènes /
}

We admit, in general, of certain forms of violence, such as physical violence, quarantine, psychological or emotional violence, verbal ferocity, threatens, intimidation and blackmailing, coercion, violence imposed through financial means and exploitation, harassment, sexual violence, destruction of property, negligence and deprivation. We even speak, especially in our nowadays society, about school-violence and bulling. Very often we make it the subject of several conferences and seminars. Up to a point, we victimize violence by presenting it as an unnatural or, at least, as an unforeseen process and by refusing to admit of the way it grows from personal to political, being a movement from the realization of a supreme emergence towards the political hypostatization of war. In virtually every circumstance, violence as a form of interrelation between people is supplemented by parameters or conditions of time, of power, of purposiveness, of vehemence or rush, even of care for someone or something and, finally, of the imaginary.

In the story of Coriolanus, ${ }^{1}$ as depicted mainly by Plutarch, ${ }^{2}$ Dionysius of Halicarnassus ${ }^{3}$ and William Shakespeare, ${ }^{4}$ we have to specifically consider, that acts of violen-

${ }^{1}$. For an account of Coriolanus as an historical figure, cf. Lehman (1952: 329-336).

2 . Ziegler (1964²: 183-279).

3 . Jacoby (1885-1905: 6.XCI-8.LXII).

${ }^{4}$. Shakespeare (2008). For a thorough account of Shapespeare's tragedy, cf. Kermode (2009: 243-254). For the appeal of Shakespeare's tragedy to modern literature, cf. Brecht (2009) and Grass (1966). 
ce, accomplished either by Coriolanus himself or by the other characters of the story, indicate a firm 'culture of violence', a definite system of values, which, within the span of Roman antiquity and history, comprises an early idea of chivalry and which aims at gloria. ${ }^{5}$ In this agenda, culture of violence matches features as military courage and bewildering and surpassing war altruism. These attributes, considered as exemplary forms of social behaviour, are to be acknowledged and further advanced within the social context, as they potentially trigger the social euphoria of the plebeians. At a second degree, they are also imposing the extraordinary as a subject open to the meta-cultural study of atavistic performances within civic life.

As known, Gaius Marcius Coriolanus, also known as Gnaeus Marcius or as Gaius Martius, was a legendary Roman aristocrat of the 5 th century B.C. As a general, he successfully led his army against the German tribe of Volscians. After defeating them and winning support from the patricians of the Roman Senate, he argued against the democratic inclinations of the plebeians, thereby making many personal enemies. He was charged with misappropriation of public funds, convicted, and permanently banished from Rome. Considering it an act of ingratitude, the exiled general turned against Rome and made allegiance with the same Volscians he had once fought against, raising an army of them and invading Roman territory. Romans came to believe that the Roman defector, who had led the enemy forces, was the reason for their defeats. Roman matrons, including his wife and mother, were sent to persuade him to call off the attack and it is said that, because of this calling off, he had a tragic end by the Volscians. Although his life assimilated that of Themistocles, ${ }^{6}$ leader of the Athenian democracy and contemporary of Coriolanus, Plutarch preferred to contrast him with the tragic life of Alcibiades. Coriolanus was thus considered to have committed acts of disloyalty to both Rome and the Volscians: in different circumstances, his persona has been treated by the Romans and the Volscians, as also in history and literature, subsequently as that of a hero and of a traitor, as a heroic and criminal figure, raising questions about the perception of crime and villainy and the affinity between them, as also presenting an example of the identification of the personal with the political dimensions of violence.

Despite what has been acknowledged as the war-type mimetic species of violence and despite the metaphorical usage of this type of violence in the peacetime processes of political negotiations, one may become the subject and/or the objective of violent force, either at the same time or subsequently, either in political terms or not, by merely standing by his word. In the story of Coriolanus, as depicted by Plutarch and Shakespeare, we may observe certain types, forms and conditions of violence; in other words, we may become aware of the norms and parameters of the nobility, the sincerity and the

\footnotetext{
${ }^{5}$ Cf. Wells (2000: 408).

${ }^{6}$ This simile relates Coriolanus' exile and flight to Attius Tullius to the banishment of Themistocles and his own flight to the Molossian king Admetus; cf. Salmon (1930: 97); Russell (1963: 27); This simile is rather ambivalent, being a product of anachronistic practices, often found in the works of literature; cf. Beam (1918: 289).
} 
legitimacy of violence, both in diction and action, both political and personal, both as a rhetorical strategy and as a way of living. The violent Coriolanus - a hero of «rages and revenges» suitable for the «Sturm und Drang» movement's Promethean type of hero - is not brutal in the sense of bestial appetites but animalistic and passionate, as he becomes the primary victim of his disjointed feelings, tendencies, beliefs, principles and political acts. His violence, contrasted with the merciful and the sense of modesty and egalitarian morality, differentiates him from Oedipus - an archetypal analogue - primarily in terms of the obsession with which he emulates the violence of his psychological soliloquy as he airs his opinions, in order to protect his 'lofty but restricted sense of honour'? In his practice, war violence and political-social behaviour become identical ${ }^{8}$, as his psychological turbulence advances towards a self-destructive way of living. The violent character in case is the character of a hero who refuses to be represented as such and who, by this paradoxical refusal and despite the romantic implications of this ethics, justifies his self via self-denial and self-destruction.

In the case of Coriolanus, violence may be said to descend from a persevering constancy, complemented by a consciousness of orphanhood, ${ }^{9}$ in which extremities speak. Violent may thus be acknowledged as heroic - particularly heroic in discord, and especially heroic when it does not promote social coherence and does not conform to social rules. This type of violence lies within the dispute between the social and the personal order of things and is related to a sentiment of appropriation as for 'something else'. Its striking discards oblivion. It is not a unificatory act against a communal enemy. Its ultimate objective of destruction lies actually within the subject acting and aims at his self-destruction in the name of the superiority of his values, the performance of which are elevated to a status of racist cruelty. Subsequently, by this conduct of life, the interfusion of treachery with sedition becomes apparent, a sequence of self-denunciations is initiated, the tragic texture of the plot is established and the intermingling of the ethical with the aesthetic is crafted. Within this framework, a Machiavellian odour is to be noticed in acting violently, in the sense of a momentous feeling of sovereignty and absolutism in ideology, which are confining the freedom of the characters.

One could inquiry on the form of the ideology and its purposiveness, under which this type of violence becomes opinionated and generated. He could also wonder on the ethical validity of the virtue sustaining it, considering it as a principal consequence of certain values, which transform someone initially to a soldier, namely an instrument of this principle, and finally to the victim of it, in relation to the incongruity evolved when he internalises his deeds. This virtue of 'manliness' can be described as determination, sustenance, decisiveness and valour. In the case of Coriolanus, this virtue, which diminishes his humanism, derives from inclinations and from an education cleansed by the

\footnotetext{
${ }^{7}$ Cf. Lees (1950: 114).

${ }^{8}$ Cf. Proser (1963).

${ }^{9}$ Cf. Ziegler (1964³ : 1.2.1-6).
} 
presence of a fraternal persona but full of ancestral exemplars, defeminized and infused, as inherited via an Amazonian mother who despises maternal values.

Within this scope, a violent act may be considered as rational and fair, since the principle motivating it is transformed into a venerated obligation towards a monopolised and fragmented sense of patriotism and nobility. Under this principle, violent acts become apparent as the exemplary form of political behaviour: their idealistic ratio has to be demonstrated, to become explicit by words and deeds, to be confirmed and dignified, in order to bring up a sense of equation by retribution. The less humble and tolerant becomes the subject in his persistence of his fierce purposes the more his principle of action is idolised, since the idolatry of virtus entails not yielding to plebeian's political pardon. ${ }^{10}$

Fragmentation, exclusion, opposition, a growing distance in character and figures, so as the characters may easily interchange the roles of the vulgar and the monstrous and depict them as objective, and a kinship on revenge, are the characteristics of the anatomy of violence in this story. Seen in its universality, the phenomenon should be acknowledged as a universal instinct for strife and conflict, ${ }^{11}$ which rests closer to the mysterious character of a question mark - a why, lucidly illustrated in the lyric interlude of Beethoven's homonymous overture. This poetry and crude sensualism of the unrestraint and the unmerciful brings up violence as a corruptive passion, ${ }^{12}$ which is a fatherless, and headless on political terms, uncompassionate and stern idolatry of virtus, and which ends up into ruins; in the words of the Shakespearean Aufidius, the complementary alter ego of Coriolanus, ${ }^{13}$ the character of this passion lies in that 'unholy lust that draws mortal enemies together in a frenzy of mutual and self-destruction.'. ${ }^{14}$

In this way, self-destruction is promoted during a course of deliberate diminution of insightfulness, in which the 'hero' fades out and demarcates his denominations, while getting closer to his ideal and inflexible values and becoming literally absorbed by it. In this spirit, violent acts discard clarifications; by this, the privatisation of language grows up, in order to cultivate his narcissism and to help the hero in moving towards his transcendental conviction, as if following a religious ritual during which his actions are absorbed into his passion. Within this framework, the aim of language lies in its becoming incomprehensible, since expressiveness could be considered as an act of yielding to scepticism.

If one would like to further investigate upon the notion of self-destruction through violence and in relation to the privatization of language both by words and deeds, he would have to admit that this motion of language and circulation of linguistic expressions towards silence, especially in Shakespeare's tragedy, is an expression of cannibalism, a symbolic consumption of human activities, especially of the so-called distinctive and

\footnotetext{
${ }^{10}$ On the role of the plebeians and the political abilities of the lower classes, cf. Winter (2012).

${ }^{11}$ Cf. McAlindon (1993: 4).

${ }^{12}$ Cf. Kassel (1965: 1452b11-13).

${ }^{13}$ Cf. Hunt (1991).

${ }^{14}$ Cf. Rackin (1983: 72).
} 
distinguished ones, aiming at the self-consumption of the hero as the final end. In this sense, the leading violent figure insinuates the absorbance of everything humble, human and mortal to the immortality of his code of honour. In this turbulence of psychological torture, Coriolanus stands as the hero who pulls the mob down to the silence of the abyss and shows that a legion and a civic community are alike to each other: in a sense close to Montaigne's depiction of literal cannibalism, ${ }^{15}$ both societies, the military and the civic, are cannibalistic, since they are constituted by people actually, including its metaphorical-symbolic instantiations, eating one another alive $\mathrm{e}^{16}$ and at the same time presenting themselves as ratifying the subsistence of their other halves. If communal language may become hysterical, if speech is war, if society fails to meet its end by incorporating its finest members, private language leads to silence as the incorporation of wordings, concord may be found in the depth of the abyss, the consumption of social commodities (such as fresh water and food), as also the interrelations of ingratitude within society, is transformed into a mutual consumption of beings and is causing the downfall and extinction of the community in a quasi-mystical, ritual process.

Violent acts are always acts of conflict: in their most eminent sense they are acts of a conflict between the will of the individual and the customs of society. ${ }^{17}$ Violence, especially political violence, entails a certain sense of loyalty, different and in most cases higher to the family loyalty or to loyalty owed to the state or any other expectation for allegiance. ${ }^{18}$

Political obligations cannot be narrowed into economic transactions and cost-benefit calculations cannot match a political economy of gratuity. Moreover, arithmetic equality of gratitude cannot be considered as good. ${ }^{19}$ For these reasons, Rome, the city of Cain, and Volumnia, who instilled in Coriolanus the conviction that violence is lovely and to be loved ${ }^{20}$, stand as cannibalistic symbols of ingratitude. It is this lack of gratitude and its cover of deceitfulness as for the political deeds within the polis that constitute the cannibalistic essence of political notions and of language-expressions within the state affairs. A political language aiming at the persuasion of the others, preaching and practicing fraudulence in order to achieve one's interest, according to which 'everyone is profoundly committed to upholding conventions in which no one believes', ${ }^{21}$ cannot represent truth; on the contrary, it validates speech as rotten ${ }^{22}$ and does not suit the integrity of

15 Cf. the essay On Cannibals; Montaigne (1952: 91-98).

${ }^{16}$ Cf. Cavell (1983: 17).

${ }^{17}$ Cf. Mendl (1928: 177). This programmatic character of Beethoven's ouverture introduces the affiliation in persona between Coriolanus and Napoleon, seen as a Coriolanean personality within the climate of Eroica; cf. Bekker (1932). On the universality of this type of character, cf. Wagner (1914: 114-117) and Kramer (1995: 270-271).

${ }^{18}$ Cf. MacKay (1962: 173).

${ }^{19}$ Cf. T. Aquinas, ST II ii, 106, 6 and Leithart (2006: 345).

${ }^{20}$ McAlindon (1993: 12).

${ }^{21}$ Cf. Greenblatt (1980: 13).

${ }^{22}$ Shakespeare (2008: 3.2.54-63). 
a man. Coriolanus' impersonated political violence suggests an act of reducing actuality by caustic responses and explosive, fulminating deeds that easily appear as irrational. But, within this framework, the irrationality of the hero's deeds may be clearly justified: his irrational violence envisions the inescapable, quite as Adorno has noticed, ${ }^{23}$ that in an irrational world the irrational response may be the only rational one. ${ }^{24}$ This ratio of Coriolanus is contrary to the pathology of the 'O-ratios', contrary to the battles of interest and expectations of future rewards, contrary to political power and to elegant, oratorical discourse, advancing deception and employing wording not to express things but to get them done. His language and his theory of action, which deliberately reflects the belief in one's thoughts and deeds and is thus not suitable to be opinionated and publicly performed in front of the constitutional violence of the plebeian masses, is representational. The speech acts suggested by the hero are to be executed retrospectively, while public audience asks for things to be said prospectively and with a delusionary, oratorical efficacy, which disdains criticism. ${ }^{25}$ In his sense, the way 'the world is ordered' and its solipsistic and mendacious universe differ from 'the order of the world', which has a performative character in terms of its authenticity and which reflects a sense of inner rightness.

Within this conception of the whole story of Coriolanus the questions what stands as actually present and rightful and who is actually banished ${ }^{26}$ may be just seen as false wordings of the genuine problem at issue: what is the actual meaning? - namely, what is the actual meaning of running such a violent life? on one hand and what is the real subject at issue? on the other. Perhaps further study will bring up similarities between the persona of Coriolanus and his violent deeds and feelings with such attitudes towards life as those noticed in self-descriptive and self-destructive heroes of contemporary world: Yukio Mishima seems, for example, to have run his life in an approximate mode. But, on the other hand and in accordance with the above-mentioned questions, one may reflect that the answer to Coriolanus' internally violent persona may be undeniably sketched when discerning that, although we all know that violence breeds violence, no one seems to know, since unjust peace is transformed into war, how peace breeds peace. ${ }^{27}$

\footnotetext{
${ }^{23}$ Cf. Adorno (1994: 114).

${ }^{24}$ Cf. Plotz (1996: 810).

25 Plotz (1996: 820).

${ }^{26}$ On the question "Who is banished", Plotz (1996: 819-821).

${ }^{27}$ Cf. Zapata (1972: 1).
} 


\section{BIBLIOGRAPHY}

Adorno, T., 1994, The Stars down to Earth and Other Essays in the Irrational in Culture, S. Crook (ed.), London.

BEAM, J.N., 1918, Hermann Kirchner's Coriolanus, PMLA 33 [2], p. 269-301.

BEKKer, P.J., 1932, Beethoven, London.

BRECHT, B., 2009, Coriolanus, London.

Cavell, S., 1983, “»Who Does the Wolf love? « Reading Coriolanus,” Representations 3, pp. 1-20.

Grass, G., 1966, Die Plebejer proben den Aufstand. Ein deutsches Trauerspiel, Berlin.

GreenblatT, S., 1980, Renaissance Self-fashioning. From More to Shakespeare, London.

Hunt, M., 1991, “»Violents’t « Complementarity: The Double Warriors of Coriolanus”, Studies in English Literature, 1500-1900 31 [2], pp. 309-325.

JACOBY, K., 1885-1905, Dionysii Halicarnasei Antiquitatum Romanarum Quae Supersunt, Leipzig.

KASSEL, R., 1965, Aristotelis de arte poetica liber, Oxford.

Kermode, F., 2009, Shakespeare's Language, London.

Kramer, A., 1995, “The Strange Case of Beethoven's Coriolan. Romantic Aesthetics, Modern Subjectivity, and the Cult of Shakespeare," The Musical Quarterly 79 [2], pp. 256-280.

LeEs, F.N., 1950, “Coriolanus, Aristotle, and Bacon,” The Review of English Studies 1 [2], pp. 114-125.

Lehman, A.D., 1952, “The Coriolanus Story in Antiquity”” The Classical Journal, 47 [8], pp. 329-336.

LeIthaRT P.J., 2006, “City of in-gratia: Roman ingratitude in Shakespeare's Coriolanus," Literature \& Theology 20 [4], pp. 341-360.

MACKAy, L.A., 1962, “Antigone, Coriolanus and Hegel,” Transactions and Proceedings of the American Philological Association 93, pp. 166-174.

McAlindon, T., 1993, “Coriolanus: An Essentialist Tragedy,” The Review of English Studies 44 [176], Nov. 1993, pp. 502-520.

MENDL, R.W.S., 1928, "Beethoven as a Writer of Programme Music," The Musical Quarterly 14 [2], pp. $172-177$. Montaigne, M.E. de, 1952, The Essays, W. Benton (ed.), London.

Plotz, J., 1996, “Coriolanus and the Failure of Performatives," English Literary History 63 [4], pp. 709-732.

Proser, M., 1963, “Coriolanus The Constant Warrior and the State," College English 24 [7], pp. 507-512.

RACKIN, P., 1983, “«Coriolanus»: Shakespeare's Anatomy of «Virtus»”, Modern Language Studies 13 [2], pp. 68-79.

RuSSELL, D.A., 1963, “Plutarch's Life of Coriolanus,” The Journal of Roman Studies 53, pp. 21-28.

SAlmon, E.T., 1930, "Historical Elements in the History of Coriolanus," The Classical Quarterly, 24 [2], pp. 96-101.

Shakespeare, W., 2008, The Tragedy of Coriolanus, R.B. Parker (ed.), Oxford.

WAGNER, R., 1914, “Ouvertüre zu Coriolan”, in: R. Wagner, Gesammelte Schriften, vol. 9, Leipzig.

Wells, R.H., 2000, “Manhood and Chevalrie: Coriolanus, Prince Henry, and the Chivalric Revival,” The Review of English Studies, 51 [203], pp. 395-422.

Winter, K. de, 2012, The political awareness of the plebeians in Coriolanus, Amazon Digital Services.

ZAPATA, E., 1972, “Whose Violence?," Black Flag 1 [8] (reproduced in the Bulletin of the Kate Sharpley Library 10 [2001]).

ZIEGLER, K., 1964³, Plutarchi Vitae Parallelae, vol. 1.2, Leipzig. 
A POSTOLOS N. STAVELAS The Aesthetics of Violence in the Case of Gaius Marcius Coriolanus / Athènes /

In the story of Coriolanus, as depicted mainly by Plutarch and Shakespeare, we become aware of the norms and parameters of the nobility, the sincerity and the legitimacy of violence, both in diction and action, both political and personal, both as a rhetorical strategy and as a way of living. These attributes indicate a firm culture of violence and a definite system of values, which, within the span of Roman antiquity and history, comprises an early idea of chivalry and which aims at gloria.

KEYWORDS

Coriolanus, esthétique, violence 